\title{
Zastosowanie fuzji obrazów wizyjnych i termowizyjnych do monitorowania i diagnozowania procesu spawania
}

\section{Visual and thermograph images fusion in monitoring and diagnostic of welding process application evaluation}

\section{Streszczenie}

W artykule przedstawiono wyniki zastosowania różnych metod fuzji obrazów rejestrowanych za pomocą kamer wizyjnej i termowizyjnej. Obrazy zarejestrowano podczas monitorowania procesu spawania. Obserwacji podlegał łuk spawalniczy i tworzone złącze, które obserwowano w fazie stygnięcia. Rozpatrywano obrazy zarejestrowane podczas spawania metoda GMA na dwóch różnych stanowiskach spawalniczych. Obserwację prowadzono z zastosowaniem kamer wyposażonych w różne układy optyczne. W artykule przeprowadzono analizę wpływu parametrów układu optycznego na wyniki fuzji obrazów. Analizie poddano również sposób przetwarzania wstępnego obrazów w celu ich wzajemnego dopasowania. Z badań wynika, że obraz po fuzji zawiera zagregowane informacje, przydatne do monitorowania i oceny jakości procesu spawania w trybie on-line.

\section{Wstęp}

Proces spawania można traktować jako uporządkowany proces, którego wynikiem jest połączenie nierozłączne. Z punktu widzenia diagnozowania procesu spawania przyjmuje się założenie, że właściwości złącza spawanego, a w szczególności jego niezgodności, są symptomami świadczącymi o nieprawidłowościach występujących w procesie spawania.

Mgr inż. Wojciech Jamrozik, dr inż. Marek Fidali, mgr inż. Anna Bzymek, dr inż. Anna Timofiejczuk - Politechnika Śląska, Gliwice.

\section{Abstract}

Results of different methods of margining thermal and visual images are presented in the paper. Images were recorded in the welding process. Welding arc and joint in cooling phase were observed. Images in the GMA welding on two different welding stations were obtained.

Cameras with different optics were used in the research. The analysis of influence of optic parameters on the image fusion were made. The image preprocessing for matching them together were also analyzed. Results are shown that the image after fusion merged information useful in monitoring and quality on-line testing of welding process includes.
Podczas trwania procesu spawania, sygnały zawierające informacje o jego stanie mogą być pozyskiwane $z$ różnych kanałów informacyjnych. Jedną z możliwości pozyskiwania informacji diagnostycznej jest prowadzenie obserwacji promieniowania elektromagnetycznego w zakresie widzialnym i podczerwieni z zastosowaniem kamer rejestrujących sekwencje obrazów wizyjnych i termowizyjnych. Sekwencja zarejestrowanych obrazów może być w takim przypadku rozumiana jako wielowymiarowy sygnał opisujący zmiany jasności (w przypadku obrazów wizyjnych) i temperatury (w przypadku obrazów termowizyjnych) w czasie. Przez sygnał rozumiany jest przebieg dowolnej wielkości fizycznej w czasie, będącej nośnikiem informacji. 
Badania nad możliwościami zastosowania wizyjnych i termowizyjnych systemów kontroli procesu spawania prowadzone są na świecie od połowy lat 90 . Główne obszary badań nad zastosowaniami systemów wizyjnych $w$ spawalnictwie dotyczą śledzenia [1, 2] i kontroli rozmiaru jeziorka spawalniczego [3, 4], kontroli geometrii spoiny oraz oceny jakości wykonania połączenia [5]. Prowadzono również badania dotyczące adaptacyjnej kontroli procesu spawania [6].

W Polsce prace nad zastosowaniem wizyjnych i termowizyjnych systemów monitorowania procesu spawania do oceny jakości połączenia spawanego prowadzone są m.in. w Instytucie Spawalnictwa w Gliwicach i skupiają się na analizie zmian widma promieniowania elektromagnetycznego podczas procesu spawania $[7,8]$. W innych ośrodkach podjęto również działania związane z określeniem cyklu cieplnego procesu napawania z użyciem kamery termowizyjnej [9]. Badania dotyczące detekcji spoiny oraz oceny jej geometrii, gdzie zastosowano dwie kamery CCD oraz oświetlenie strukturalne, zostały opisane w [10].

Monitorowanie procesu spawania $z$ jednoczesnym zastosowaniem kamer wizyjnej i termowizyjnej było prowadzone przez autorów w ramach projektu System oceny stanu elementów maszyn i urządzeń z zastosowaniem metod wizyjnych (PW-004/ITE/10/2006, zadanie realizowane w ramach Projektu Wieloletniego koordynowanego przez Instytut Eksploatacji w Radomiu) wykonywanego w latach 2006-2007 [11]. Podczas badań stwierdzono, że obrazy wizyjne i termowizyjne rejestrowane podczas procesu spawania mogą być analizowane łącznie metodami fuzji obrazów. W dalszej części artykułu zaprezentowano wyniki zastosowania wybranych metod fuzji obrazów do obrazów wizyjnych i termowizyjnych łuku oraz przeprowadzono ocenę przydatności metod fuzji obrazów dla potrzeb pozyskiwania informacji pomocnych przy diagnozowaniu procesu spawania.

\section{Fuzja obrazów w spawalnictwie}

Fuzja obrazów to proces łączenia dwóch lub więcej obrazów przedstawiających daną scenę lub jej fragment $w$ taki sposób, aby nowo powstały obraz niósł więcej informacji z punktu widzenia ludzkich zdolności percepcyjnych lub przetwarzania komputerowego. Można więc przyjąć, że głównym celem zastosowania fuzji obrazów jest zredukowanie niepewności i minimalizacja redundantnej informacji w obrazie wynikowym, przy jednoczesnej maksymalizacji ilości informacji relewantnej [12]. Większość technik fuzji obrazów składa się z dwóch etapów: dopasowania obrazów i agregacji obrazów.

Szeroką gamę opracowanych algorytmów agregacji obrazów można podzielić na trzy podstawowe grupy: algorytmy działające na poziomie pikseli, algorytmy działające na poziomie cech i algorytmy działające na poziomie symbolicznym [12].
Spośród wymienionych grup najszersze zastosowanie znalazły algorytmy działające na najniższym poziomie, czyli operujące bezpośrednio na pikselach. Mogą one być zaimplementowane bezpośrednio do zarejestrowanych obrazów lub obrazów poddanych różnego rodzaju transformacjom. Ponieważ w algorytmach niskiego poziomu przyjęto, że istnieją związki pomiędzy odpowiednimi pikselami wszystkich obrazów wejściowych, kluczowe znaczenie ma wzajemne dopasowanie obrazów. Istnieje wiele metod dopasowania obrazów [13]. Można je podzielić na metody bazujące na znacznikach (markerach) umieszczanych na obrazie oraz metody bazujące na intensywności pikseli dopasowywanych obrazów. Metody oparte na markerach wymagają zidentyfikowania na obrazach wejściowych korespondujących cech (punkty, krawędzie itp.). $W$ metodach bazujących na intensywności ten etap jest pomijany. W procesie dopasowania ważny jest wybór odpowiedniego modelu transformacji położenia pikseli obrazu dopasowywanego względem obrazu odniesienia. Model transformacji powinien w efektywny sposób opisywać i minimalizować zniekształcenia pomiędzy dopasowywanymi obrazami. Proces dopasowania może być oparty na modelu transformacji uwzględniającej podobieństwo obiektów, transformacji afinicznej, czy też transformacji elastycznej.

W spawalnictwie fuzja obrazów znalazła zastosowanie $w$ kontroli jakości wykonanych połączeń spawanych z wykorzystaniem badań rentgenograficznych [14]. Autorom nie są znane publikacje dotyczące zastosowania fuzji obrazów do monitorowania procesu spawania, zatem proponowane podejście polegające na łącznej analizie obrazów wizyjnych i termowizyjnych jest nowatorskie.

\section{Wyniki badań}

Opisane metody dopasowania i agregacji obrazów, zostały zastosowane do obrazów będących wynikiem dwóch eksperymentów. Stanowiska spawalnicze, warunki prowadzenia eksperymentów oraz szczegółowy opis wyników przetwarzania i analizy obrazów syntetycznych, po fuzji, przedstawiono poniżej. Pokazano wyniki zastosowania tych operacji uzyskane za pomocą różnych algorytmów.

\section{Analiza obrazów}

W badaniach nad oceną przydatności zastosowania fuzji obrazów do monitorowania procesu spawania wykorzystano obrazy termowizyjne i wizyjne zarejestrowane podczas spawania metodą GMA na dwóch różnych stanowiskach spawalniczych. Na pierwszym stanowisku możliwe było wykonywanie liniowych połączeń spawanych (rys. 1a), natomiast na drugim złączy obwodowych (rys. 1b). 


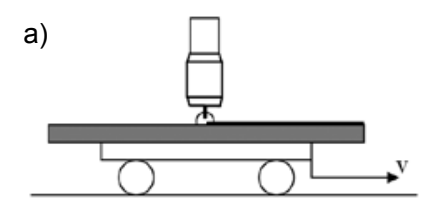

b)
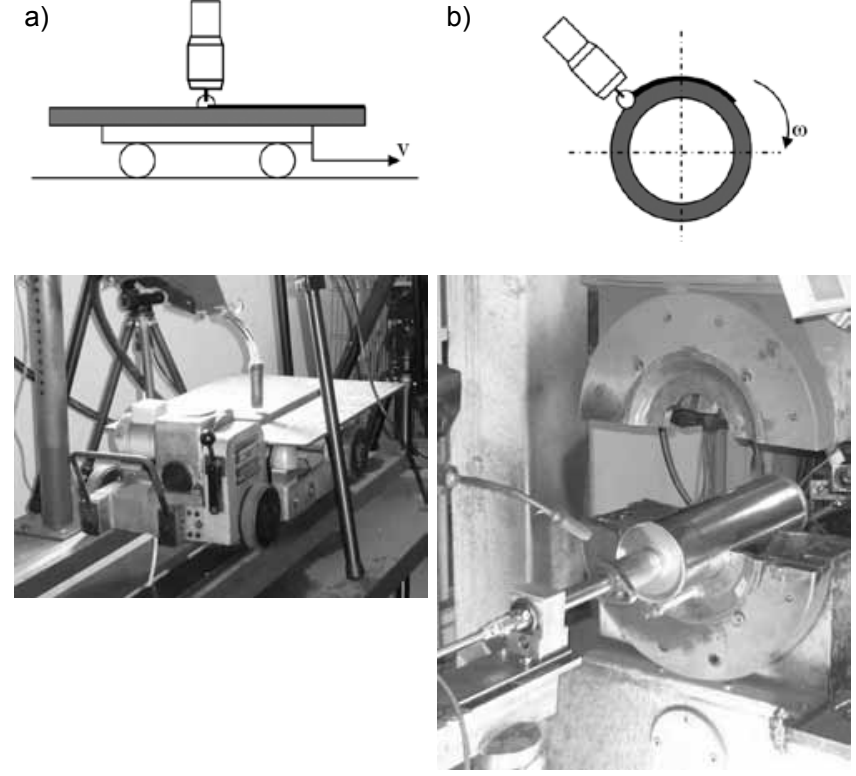

Rys. 1. Stanowiska spawalnicze wykorzystane w badaniach Fig. 1. Welding stations used in the research

W pierwszym przypadku elementy spawane usytuowano na wózku poruszającym się względem nieruchomego palnika. Wózek poruszał się ruchem jednostajnym prostoliniowym, $\mathrm{z}$ zadaną prędkością. W drugim przypadku elementy spawane umieszczono w specjalnie przygotowanym uchwycie (obrotniku), który zapewniał ich obrót względem własnej osi oraz względem nieruchomego palnika z zadaną, stałą prędkością obrotową.

Proces spawania obserwowano za pomocą kamer światła widzialnego i podczerwieni. W obu rozpatrywanych przypadkach zastosowano kamerę termowizyjną VarioCam firmy Infratec o rozdzielczości w podczerwieni 320x240px i przemysłową kamerę CCD firmy Imaging Source o rozdzielczości 786x1024px. Obie kamery obserwowały łuk spawalniczy i rejestrowały obrazy z prędkością $25 \mathrm{kla} / \mathrm{s}$. W zależności od stanowiska spawalniczego, w kamerach zastosowano różne układy optyczne. W przypadku spawania liniowego w obu kamerach zastosowano obiektywy o ogniskowej $50 \mathrm{~mm}$ (rys. 1a). W drugim przypadku, gdy spawanie odbywało się na obwodzie, kamerę termowizyjną wyposażono w obiektyw o ogniskowej $25 \mathrm{~mm}$, a kamerę wizyjną w obiektyw o ogniskowej $50 \mathrm{~mm}$ (rys. 1b). Podczas eksperymentów zarejestrowano dwa zestawy obrazów, różniących się polem widzenia i rozdzielczością.

\section{Dopasowanie obrazów}

Dla wybranych obrazów, zarejestrowanych w świetle widzialnym i w podczerwieni (termogramy), wykonano operację dopasowania, poprzedzoną wstępnym przetwarzaniem polegającym na wyborze obszaru
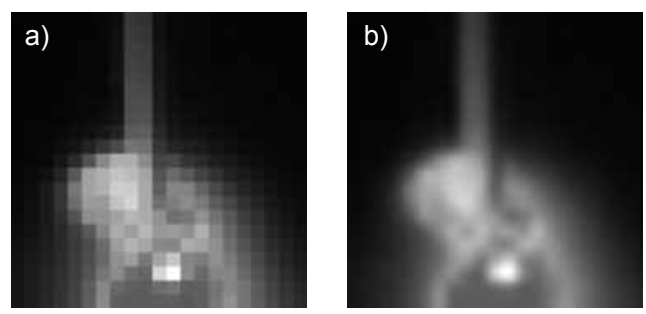

Rys. 2. Termogramy po skalowaniu przez: a) zwiększanie rozmiaru piksela, b) interpolację

Fig. 2. Thermograph images after adjustment:a) pixel size increase, b) interpolation

zainteresowania, w tym przypadku obszaru łuku, a następnie wstępnym dopasowaniu wymiarów obrazów. Dopasowanie przeprowadzono w taki sposób, aby obiekty widoczne na obrazach miały zbliżone wymiary. Konieczność dopasowania wielkości obiektów wynikała $z$ różnic $w$ rozdzielczościach matryc zastosowanych kamer. W opisywanym przypadku termogram, w stosunku do obrazu zarejestrowanego w świetle widzialnym, ma ok. 8-krotnie mniejszą rozdzielczość, zatem obiekty są mniejsze od obiektów widzianych przez kamerę wizyjną. Dopasowanie rozmiarów obiektów na obrazie realizowane jest na trzy sposoby: zmniejszenie rozmiaru obrazu o większej rozdzielczości, zwiększając rozmiar obrazu o mniejszej rozdzielczości lub użyskanie takich samych rozmiarów obu obrazów. W badaniach wykorzystano zwiększenie rozmiaru obrazu termowizyjnego dwoma metodami: przez zwiększenie rozmiaru termopiksela, czyli pomnożenie rozmiaru pojedynczego piksela przez zadany współczynnik skali oraz przez interpolację, polegającą na uzupełnieniu obrazu o nowe pośrednie piksele, których wartości wyznaczane są na podstawie znajomości wartości pierwotnych pikseli sąsiadujących (rys. 1).

Obrazy po operacji wstępnego przetwarzania dopasowano do siebie, stosując metodę maksymalizacji informacji wzajemnej, która umożliwia iteracyjną zmianę parametrów charakterystycznych oraz obliczanie miary informacji wzajemnej dla pary obrazów dopasowanych w każdym kroku iteracji $[13,15]$. Jako najlepsze dopasowanie przyjmuje się zestaw parametrów, dla którego osiągnięto maksymalną wartość informacji wzajemnej obliczoną ze wzoru (1). Entropia obliczana jest z zależności (2), a entropia łączna z zależności (3):

$$
I(A, B)=H(A)+H(B)-H(A, B)
$$

gdzie: $H(A)$ i $H(B)$ - entropia Shannona obrazów $A$ i $B, H(A, B)$ - łączna (produktywna) entropia obrazów $A$ i $B$;

$$
H(A)=\sum_{i} p_{i} \log \frac{1}{p_{i}}=-\sum_{i} p_{i} \log p_{a}
$$

gdzie: $p_{i}$ - prawdopodobieństwo wystąpienia w obrazie $A$ piksela o danym poziomie szarości; 


$$
H(A, B)=-\sum_{i, j} p(i, j) \log p(i, j)
$$

gdzie: $p(i, j)$ - łączne prawdopodobieństwo wystąpienia pikseli o danym poziomie szarości na obu obrazach $(A$ i $B)$, wyznaczone na podstawie ich łącznego histogramu.

Przy dopasowaniu obrazów łuku spawalniczego zdecydowano się na wykorzystanie modelu transformacji przez podobieństwo z trzema parametrami związanymi z: przesunięciem obrazów względem siebie w kierunku poziomym (wzdłuż osi $x$ ), przesunięciem obrazów względem siebie w kierunku pionowym (wzdłuż osi y), skalowaniem obrazu termowizyjnego względem obrazu zarejestrowanego w świetle widzialnym.

Współczynnik rotacji w tym przypadku został pominięty ze względu na brak względnego obrotu między obrazami w wyniku określonego sposobu zamontowania kamer na stanowisku pomiarowym.

Próby dopasowania przeprowadzono dla wszystkich zarejestrowanych par obrazów. Przykładowe wyniki dopasowania przedstawiono na rysunku 3, w tym obraz łuku zarejestrowany przez kamerę działającą w zakresie światła widzialnego (rys. 3a) oraz obraz termowizyjny poddany wstępnemu przetwarzaniu polegającemu na zmianie jego rozmiarów przez skalowanie piksela (rys. 3b) i interpolację (rys. 3c). W celu lepszego zilustrowania wyników dopasowania odpowiednie obrazy, zarejestrowane przez dwie kamery, nałożono na siebie, uśredniając wartości odpowiadających sobie pikseli na obu obrazach (rys. 3d i 3e). Potwierdziło to, że możliwe jest uzyskanie nowego obrazu zawierającego cechy obrazów składowych, które mogą być lepiej uwypuklone dzięki zastosowaniu agregacji informacji, co stanowi drugi etap operacji fuzji obrazów.
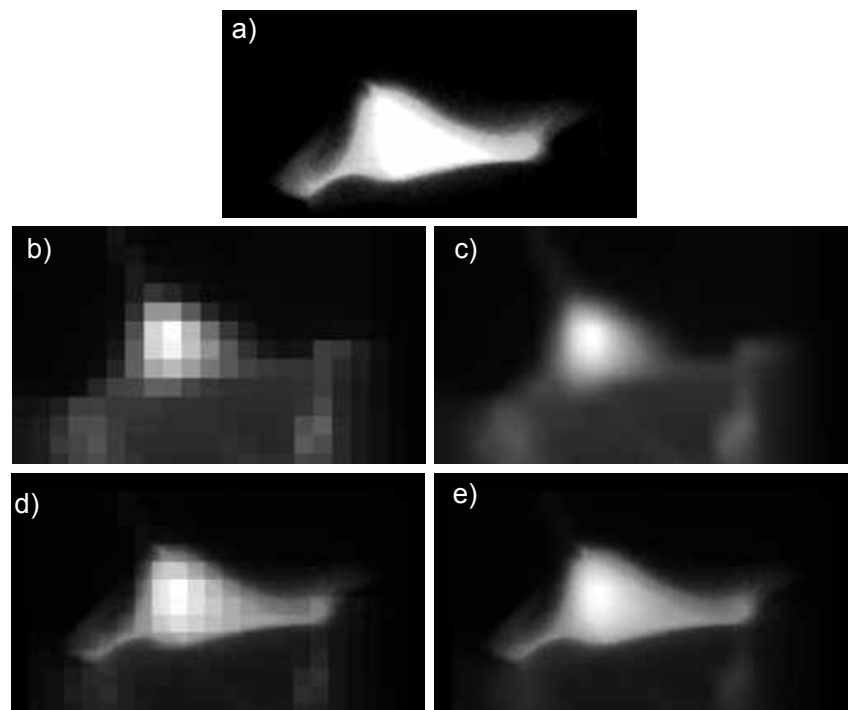

Rys. 3. Dopasowywanie i nakładanie obrazów

Fig. 3. Images matching and merging

\section{Agregacja obrazów}

Agregacja dwóch dopasowanych obrazów na poziomie pikseli może być realizowana z wykorzystaniem jednej $z$ wielu metod $[4,12,16,17]$. Po analizie temperatury $[16,18 \div 20]$ zdecydowano się na zbadanie metod agregacji opartych na zastosowaniu: piramidy kontrastu (con), dyskretnej transformaty falkowej - falka $\operatorname{DBSS}(2,2)(d w b)$, piramidy fsd $(f s d)$, piramidy gradientu (gra), piramidy laplasjanów (lap), piramidy różnic morfologicznych $(\mathrm{mod})$, piramidy proporcjonalności ratio pyramid (rat), oraz wykorzystaniu wartości maksymalnej - nieliniowy operator max (max), wartości średniej (mea), wartości minimalnej - nieliniowy operator min ( $\min )$, analizy składowych głównych ( $p c a)$, transformaty falkowej niezmiennej względem przesunięcia - shift invariant dwt, falka haar (sih).

Wśród wymienionych metod można wyróżnić trzy grupy: metody jednopunktowe, oparte na piramidach oraz transformacie falkowej. W metodach wieloskalowych wykorzystywane są serie obrazów uzyskanych w wyniku filtracji dolnoprzepustowej lub pasmowo-przepustowej obrazów pierwotnych, przy czym każdy obraz w serii ma mniejszą rozdzielczość od swojego poprzednika. Przykładowo kolejne obrazy w piramidzie laplasjanów tworzone są jako różnica obrazu na wyższym poziomie piramidy i obrazu na niższym poziomie piramidy Gaussa [21]. Każdy obraz w piramidzie powstaje przez redukcję liczby pikseli, gdzie wartość nowego piksela jest średnią kilku sąsiednich pikseli. Rozmiar obrazu wynikowego jest powiększany do rozmiaru obrazu na wyższym stopniu piramidy przez interpolację.

W przypadku piramidy kontrastu, operację odejmowania zastosowaną w piramidzie laplasjanów zastąpiono dzieleniem [22]. Agregacja obrazów odbywa się na najniższym poziomie piramidy, gdzie wartość poziomu szarości piksela wynikowego może być wyznaczona np. jako wartość średnia arytmetyczna lub ważona odpowiadających mu pikseli na obrazach wejściowych. Wykorzystuje się w tym celu np. test logiczny lub różnego typu statystyki, np. średni gradient jasności w określonym sąsiedztwie. Obraz wynikowy jest uzyskiwany w wyniku zastosowania transformacji odwrotnej do użytej na etapie generowania piramidy.

W przypadku metod wykorzystujących transformatę falkową (dyskretną), bądź jej modyfikację, niezmienną względem przesunięcia, kolejne obrazy piramidy obliczane są w wyniku liniowej dekompozycji, z zastosowaniem funkcji bazowych (falek) [23, 24]. Zastosowanie różnych funkcji bazowych umożliwia uzyskanie obrazów o cechach wymaganych w danym zastosowaniu, np. przez wzmocnienie obiektów o niskim kontraście względem tła. Agregacja odbywa się na najniższym poziomie dekompozycji, z wykorzystaniem metod analogicznych do stosowanych w przypadku przekształceń wielkoskalowych. Obraz wynikowy jest generowany jako wynik odwrotnej transformaty falkowej. 

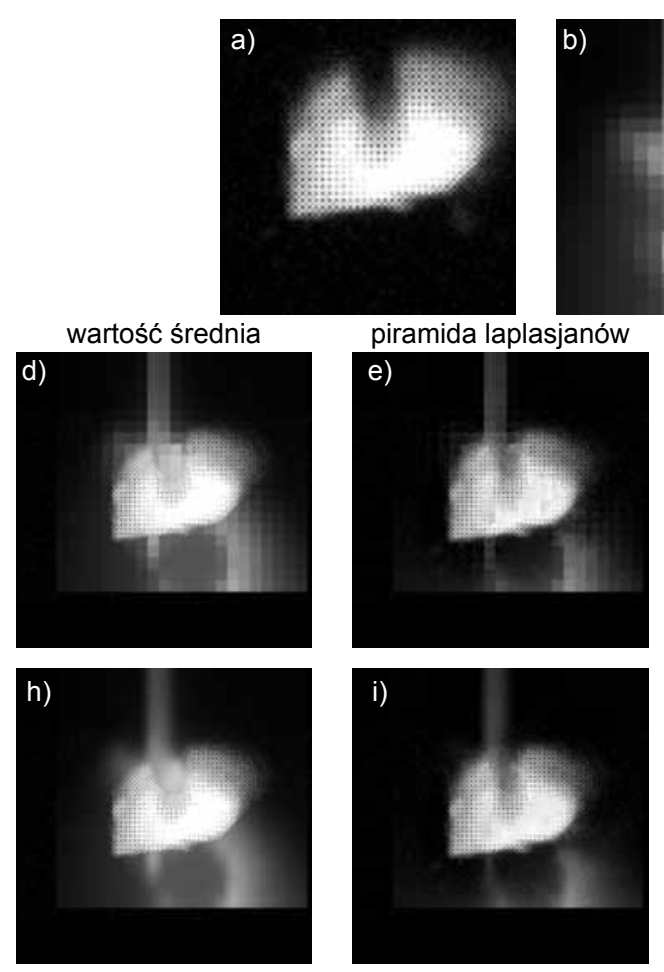

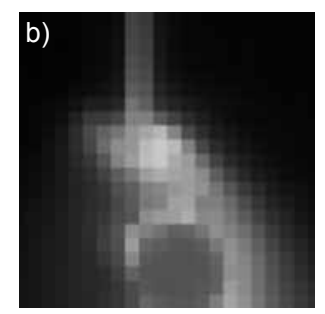

kontrast
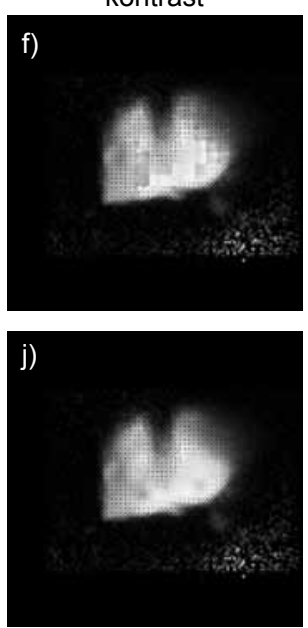

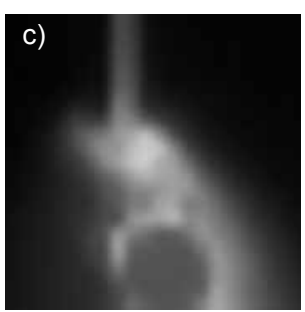

przekształcenie falkowe
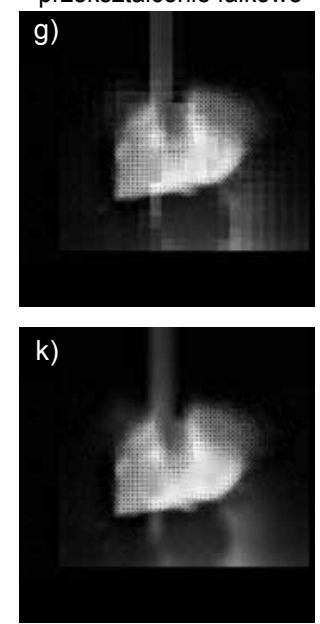

Rys. 4. Fuzja obrazów zarejestrowanych podczas spawania liniowego: a) obraz wizyjny, b) obraz termowizyjny po skalowaniu pikseli, c) obraz termowizyjny po operacji interpolacji, d $\div$ g) obrazy a) i b) po fuzji, h:k) obrazy a) i c) po fuzji Fig. 4. Fusion of images recorded in lineal welding: a) visual image, b) thermograph image after adjustment, b) thermograph image after interpolation, $d \div$ ) images a) and b) after fusion, $h \div k$ ) images a) and c) after fusion
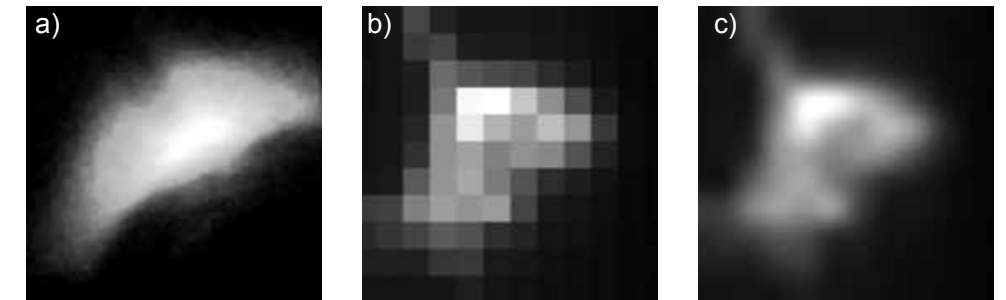

wartość średnia
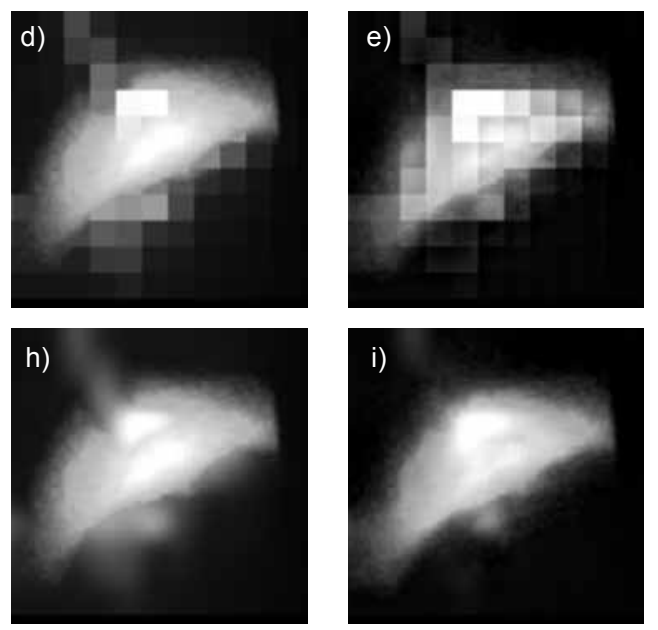

kontrast
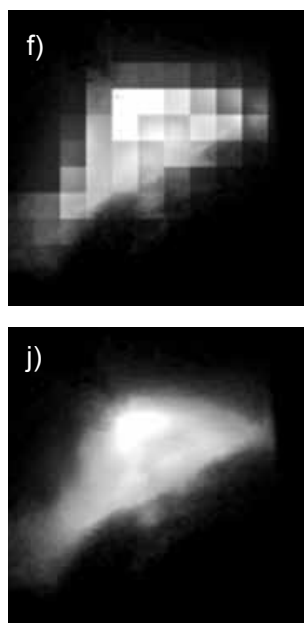

przekształcenie falkowe
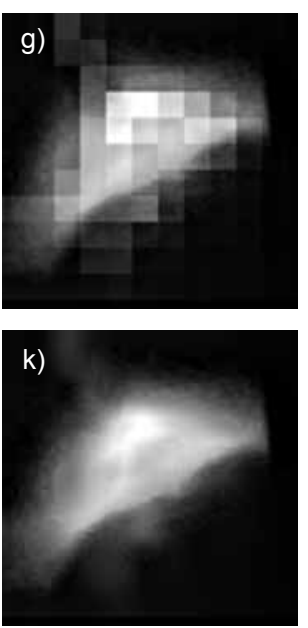

Rys. 5. Fuzja obrazów zarejestrowanych podczas spawania obwodowego: a) obraz wizyjny, b) obraz termowizyjny po skalowaniu pikseli, c) obraz termowizyjny po operacji interpolacji, d $\div$ g) obrazy a) i b) po fuzji, $h \div k$ ) obrazy a) i c) po fuzji.

Fig. 5. Fusion of images recorded in encyclical welding a) visual image, b) thermograph image after adjustment, b) thermograph image after interpolation, $d \div \mathrm{g}$ ) images a) and b) after fusion, $h \div k$ ) images a) and c) after fusion
Oprócz opisanych metod, podczas realizacji badań zaproponowano zastosowanie nieliniowych operatorów jednopunktowych maksimum i minimum. Operatory te nie wymagają przekształcenia wielkoskalowego, a obraz wynikowy jest generowany w wyniku wyboru maksymalnej wartości poziomu szarości danego piksela z obrazów wejściowych.
Na rysunkach 4 i 5 przedstawiono przykładowe wyniki zastosowania fuzji obrazów zarejestrowanych podczas spawania liniowego i obwodowego. Operację fuzji przeprowadzono na podstawie: wyznaczania wartości średniej obrazów wejściowych oraz metod piramidy laplasjanów, kontrastu i przekształcenia falkowego niezmiennego względem przesunięcia. 


\section{Ocena obrazów po fuzji}

Efektem działania metod fuzji obrazów są obrazy wynikowe zawierające informacje zawarte na obrazach zarejestrowanych. Na rysunkach 4 i 5 obrazy będące wynikiem fuzji obrazów wizyjnych i termowizyjnych łuku spawalniczego różnią się, a zatem mają różną zawartość informacyjną uzależnioną m.in. od usytuowania, rozdzielczości i optyki kamer, sposobu przetwarzania wstępnego obrazów i metod fuzji obrazów (dopasowania i agregacji). $Z$ punktu widzenia analizy obrazu, istotna jest maksymalizacja informacji relewantnej.

Obrazy po fuzji można ocenić dwiema metodami: subiektywnej oceny jakościowej lub obiektywnej oceny ilościowej. W pierwszym przypadku obraz oceniany jest w kontekście wcześniej sformułowanych wymagań dotyczących jakości i zawartości informacyjnej. W drugim przypadku stosowane są oceny ilościowe, przeprowadzane na podstawie obrazów wejściowych i wynikowych [25].

Podczas prowadzonych badań wykorzystano obie metody oceny obrazów po fuzji. W pierwszym przypadku wybrane obrazy oceniało niezależnie dwóch ekspertów na podstawie kryteriów jakości obrazu i jego przydatności do dalszej analizy dotyczącej stabilności procesu spawania. Eksperci dokonali wyboru metody fuzji dla rozpatrywanych sposobów spawania i metod wstępnego przetwarzania. Wyniki tej oceny zamieszczono w tablicy I.

Analiza wyników jest rozbieżna. Na rysunku 6 zaprezentowano obrazy po fuzji, uznane przez ekspertów za najlepsze.Trudno było ocenić obrazy dopasowane przez powiększanie pikseli, które powstały na podstawie obrazów termowizyjnych o mniejszej rozdzielczości niż obrazy wizyjne. Szczególnie niejednoznaczne oceny uzyskano w przypadku obrazów termowizyjnych, pozyskanych podczas spawania obwodowego, gdzie rozrost pikseli w znacznym stopniu zmniejszył ich czytelność. Jest to efektem zastosowania układu optycznego o mniejszej ogniskowej.

Aby uniknąć niejednoznaczności w ocenie ekspertów, te same obrazy po fuzji poddano ocenie z zastosowaniem miary efektywności fuzji obrazów OIFPM (Objective Image Fusion Performance Measure) zaproponowanej w [26], zdefiniowanej w następujący sposób:

$$
Q_{p}^{A B / F}=\frac{\sum_{n=1}^{N} \sum_{m=1}^{M} Q^{A F}(n, m) w^{A}(n, m)+Q^{B F}(n, m) w^{B}(n, m)}{\sum_{i=1}^{N} \sum_{j=1}^{M}\left(w^{A}(i, j)+w^{B}(i, j)\right)}
$$

gdzie: $Q^{A F}$ i $Q^{B F}$ - wskaźniki obecności krawędzi obrazów $A$ i $B$ w obrazie po fuzji, $w^{A}$ i $w^{B}$ - wagi wskaźników.

Tablica I. Jakościowa ocena fuzji obrazów

Table I. Qualitative analysis of image fusion results

\begin{tabular}{|c|c|c|c|c|c|c|c|c|}
\hline \multirow{3}{*}{$\begin{array}{c}\text { Metoda } \\
\text { przetwarzania } \\
\text { Eksperci }\end{array}$} & \multicolumn{4}{|c|}{ Stanowisko nr 1 - spawanie liniowe } & \multicolumn{4}{|c|}{ Stanowisko nr 2 - spawanie obwodowe } \\
\hline & \multicolumn{2}{|c|}{ najlepsza metoda } & \multicolumn{2}{|c|}{ najgorsza metoda } & \multicolumn{2}{|c|}{ najlepsza metoda } & \multicolumn{2}{|c|}{ najgorsza metoda } \\
\hline & 1 & 2 & 1 & 2 & 1 & 2 & 1 & 2 \\
\hline Interpolacja & mea & $d w b$ & $\min$ & $\min$ & $\max$ & gra & con & con \\
\hline Powiększenie & lap & $d w b$ & $\min$ & $\min$ & $d w b$ & $d w b$ & $\min$ & con \\
\hline
\end{tabular}

Stanowisko nr 1 - spawanie liniowe Interpolacja
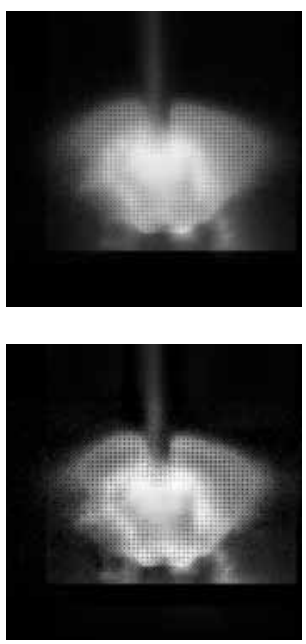

Powiększenie
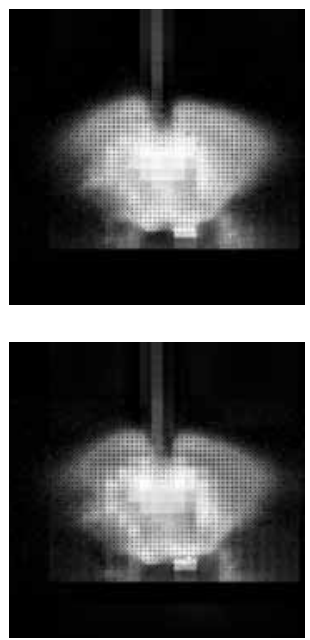

Stanowisko $\mathrm{nr} 2$ - spawanie obwodowe Interpolacja
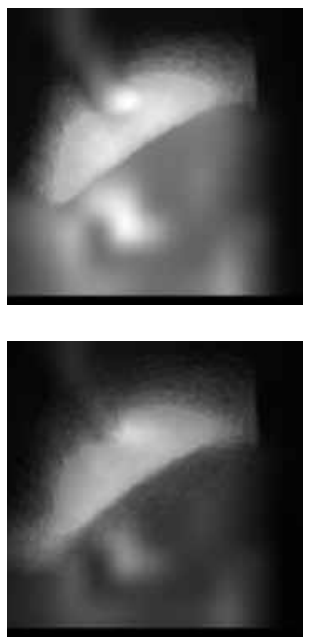

Powiększenie
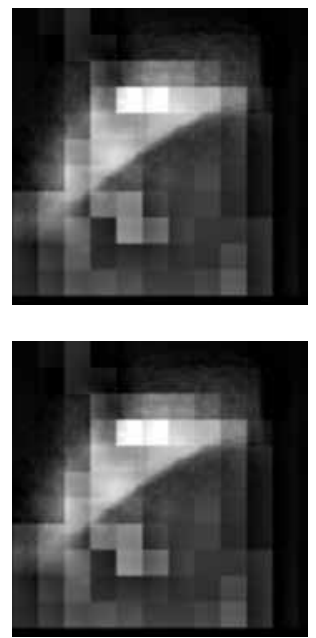

Rys. 6. Najlepsze wg oceny ekspertów obrazy po fuzji

Fig. 6. The best quality images after fusion in export opinion 
Tablica II. Ilościowa ocena fuzji obrazów z zastosowaniem miary OIFPM

Table II. OIFPM measure quantitative analysis of merged image results

\begin{tabular}{|c|c|c|c|c|c|c|c|c|}
\hline \multirow{2}{*}{$\begin{array}{c}\text { Metoda } \\
\text { przetwarzania }\end{array}$} & \multicolumn{4}{|c|}{ Stanowisko nr 1 - spawanie liniowe } & \multicolumn{4}{|c|}{ Stanowisko $\mathrm{nr} 2$ - spawanie obwodowe } \\
\hline & $\begin{array}{l}\text { wart. max. } \\
\text { OIFPM }\end{array}$ & $\begin{array}{l}\text { metoda } \\
\text { fuzji }\end{array}$ & $\begin{array}{l}\text { wart. min. } \\
\text { OIFPM }\end{array}$ & $\begin{array}{l}\text { metoda } \\
\text { fuzji }\end{array}$ & $\begin{array}{l}\text { wart. max. } \\
\text { OIFPM }\end{array}$ & $\begin{array}{l}\text { metoda } \\
\text { fuzji }\end{array}$ & $\begin{array}{l}\text { wart. min. } \\
\text { OIFPM }\end{array}$ & $\begin{array}{l}\text { metoda } \\
\text { fuzji }\end{array}$ \\
\hline Interpolacja & 0,07 & rat & 0,05 & $\min$ & 0,28 & $\max$ & 0,14 & con \\
\hline Powiększenie & 0,08 & rat & 0,06 & fsd & 0,18 & $\max$ & 0,08 & con \\
\hline
\end{tabular}

Stanowisko nr 1 - spawanie liniowe Interpolacja

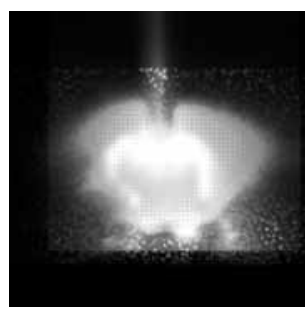

Powiększenie

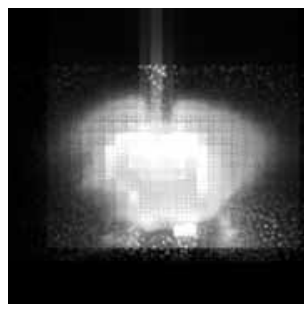

Stanowisko $\mathrm{nr} 2$ - spawanie obwodowe Interpolacja

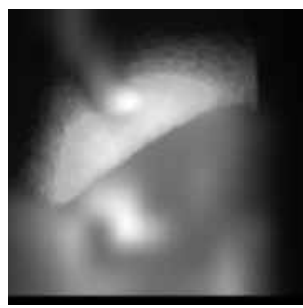

Powiększenie

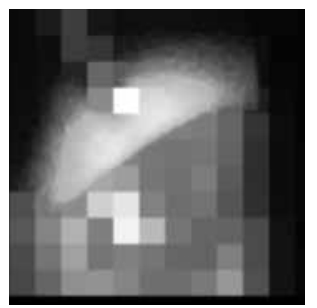

Rys. 7. Wynik fuzji metodami najwyżej ocenionymi miarą OIFPM

Fig. 7. Merged image with the highest note by OIFPM measure analysis

Zastosowana miara wynika z porównania informacji niesionych przez krawędzie obiektów na obrazach poddanych fuzji i obrazie będącym efektem fuzji. Wartość miary wynosi zero, gdy w obrazie po fuzji nie ma informacji o obiektach znajdujących się na obrazach wejściowych. W tablicy II zestawiono wyniki oceny obrazów uzyskanych różnymi metodami fuzji. Podobnie jak w przypadku oceny ekspertów, rozpatrywano wynik oceny wskazujący na najlepszą i najgorsza metodę fuzji obrazów.

Uzyskane wyniki wskazują na rozbieżności w wyborze najlepszej i najgorszej metody fuzji obrazów, w odniesieniu do oceny wykonanej przez ekspertów. Na rysunku 7 przedstawiono obrazy po fuzji z zastosowaniem metod, dla których ocena ilościowa OIFPM była najlepsza. Porównując obrazy ocenione przez ekspertów i miarę OIFPM stwierdzono, że różnice między nimi są niewielkie. Zbieżność tych ocen pozwala na stwierdzenie, że ilościowa ocena za pomocą wskaźnika OIFPM może być stosowana do oceny obrazów oraz algorytmów. Wskaźnik ten umożliwia wybór optymalnej metody fuzji obrazów.
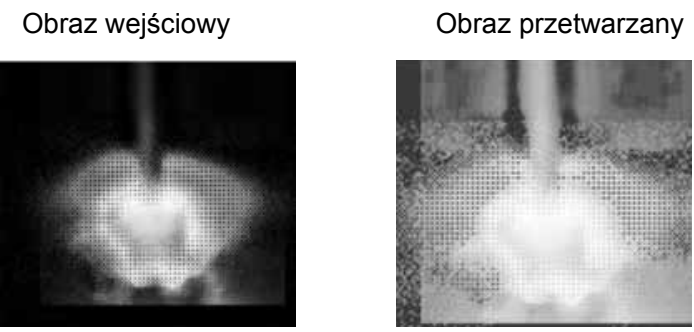

\section{Analiza obrazów po fuzji}

\section{Wstępne przetwarzanie}

Pierwszą operacją wstępnego przetwarzania jest wycięcie obszaru zainteresowania (ROI) z obrazu syntetycznego. Operacja ta jest konieczna, ponieważ obraz po fuzji zawiera elementy dwóch lub więcej obrazów składowych, które mogą być przesunięte względem siebie, czego zazwyczaj nie widać na nieprzetworzonym obrazie. Efekt ten uwidacznia się dopiero po przeprowadzonym przetwarzaniu. Na rysunku 8 jako operację przetwarzania zastosowano wyrównanie histogramu. W wyniku tej operacji uzyskano obraz homogeniczny, pozbawiony zbędnej „ramki”, niemającej żadnej wartości informacyjnej.

Procedury wstępnego przetwarzania obrazu obejmują: wyrównywanie histogramu, normalizację, filtrację oraz wyznaczanie krawędzi, a także binaryzację. W przypadku binaryzacji próg nie może być jednowartościowy, ponieważ niektóre $z$ informacji zawartych

Obraz wejściowy - wycięty ROI

ROI przetwarzany
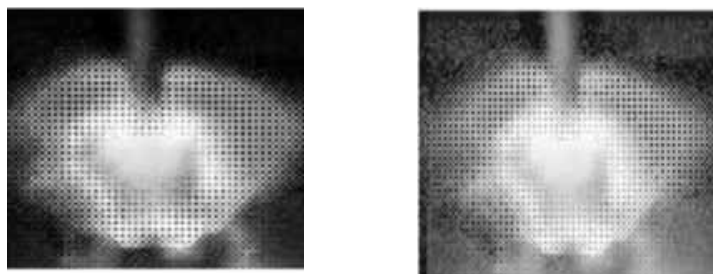

Rys. 8. Wynik zastosowania operacji wyboru ROI

Fig. 8. Results of ROI selection operation application 
Stanowisko nr 1 - spawanie liniowe

VIS

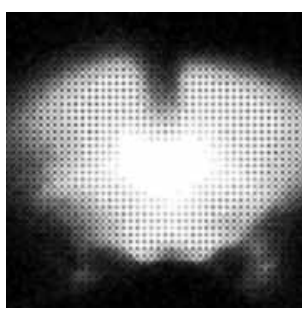

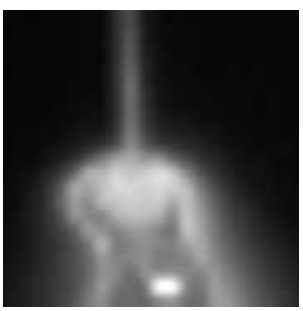

Stanowisko $\mathrm{nr} 2$ - spawanie obwodowe

VIS

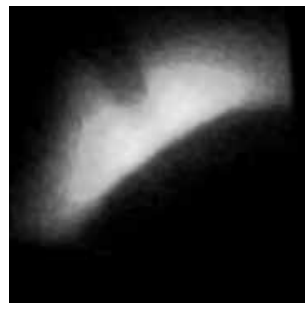

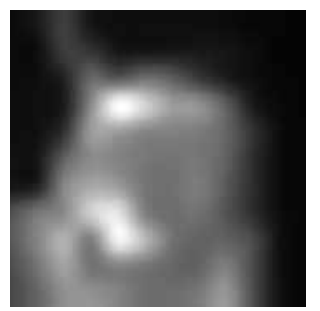

Rys. 9. Obrazy wejściowe

Fig. 9. Input images

Stanowisko nr 1 - spawanie liniowe

Interpolacja

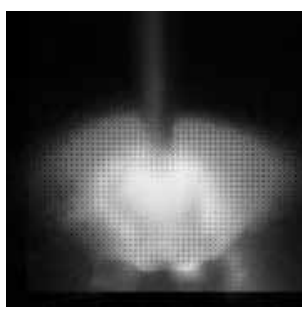

Najgorsze

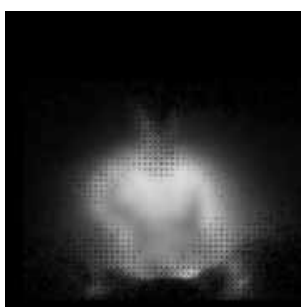

Powiększenie
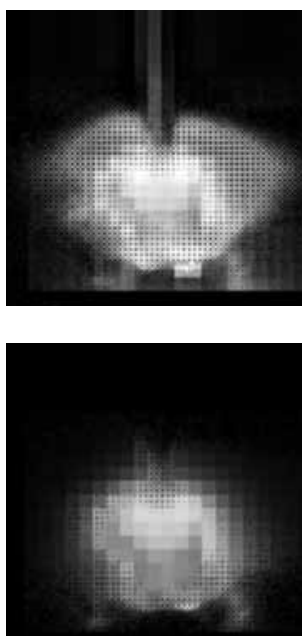

Stanowisko $\mathrm{nr} 2$ - spawanie obwodowe

Interpolacja
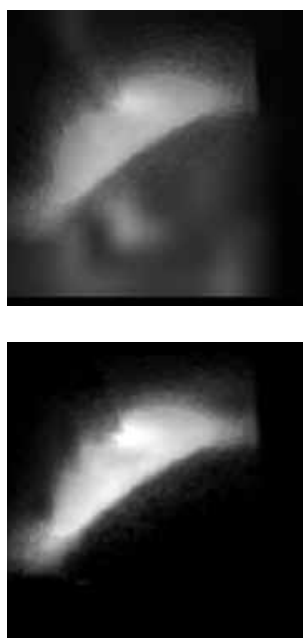

Powiększenie
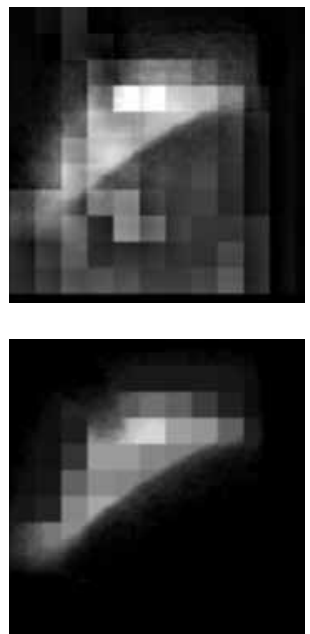

Rys. 10. Obrazy przetworzone

Fig. 10. Processed images

Z15

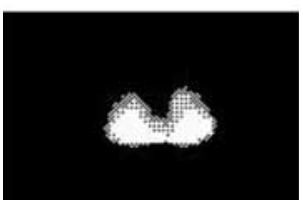

Po fuzji

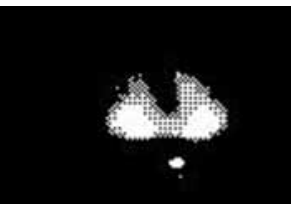

Przed fuzją

Po fuzji
Z21
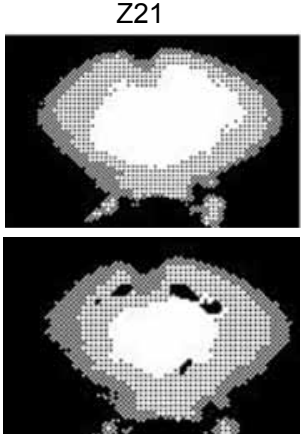

Z17
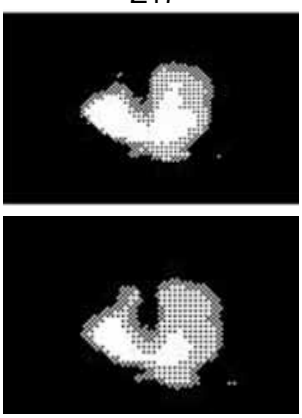

Z23
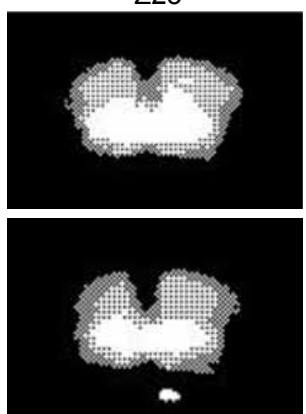

Z20
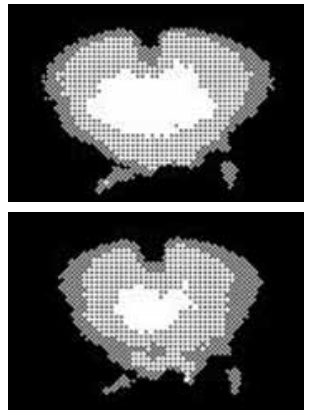

Z26
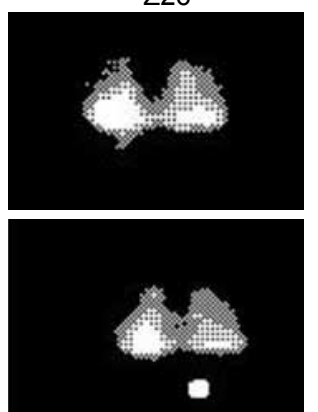

Rys. 11. Obrazy uzyskane w wyniku działania procedur przetwarzania obrazów

Fig. 11. Results of image processing procedures 
w obrazie mogą zostać odcięte. Dobrym rozwiązaniem wydaje się zastosowanie jednej z metod adaptacyjnych, umożliwiających poszukiwanie zmiennego progu określanego w poszczególnych obszarach obrazu, co umożliwia wyodrębnienie obiektu z tła.

\section{Analiza}

Ocena poprawności procesu spawania na podstawie informacji wyodrębnionych z obrazów łuku spawalniczego, rejestrowanych podczas eksperymentów, polega głównie na analizie kształtu łuku na podstawie sekwencji zbinaryzowanych obrazów po fuzji. Możliwe jest zatem wyznaczanie cech topologicznych i statystycznych odzwierciedlających kształt łuku oraz jego zmiany w czasie procesu spawania. Przykładowymi cechami są: pole powierzchni, obwód, współczynnik wydłużenia, orientacja osi, współrzędne środka ciężkości [27].

Podczas badań przetwarzano i analizowano sekwencje obrazów przed fuzją (rys. 9) oraz sekwencje obrazów po fuzji (rys.10). Obrazy uzyskane w wyniku działania procedur przetwarzania i analizy obrazów przedstawiono odpowiednio na rysunkach 11 i 12.

$\mathrm{Na}$ podstawie analizy sekwencji zdjęć pochodzących z obserwacji spawania liniowego oraz obwodowego można stwierdzić, że obrazy przed fuzją i po fuzji zawierają podobne informacje, jednak liczba pikseli zawierająca te informacje jest znacznie mniejsza na
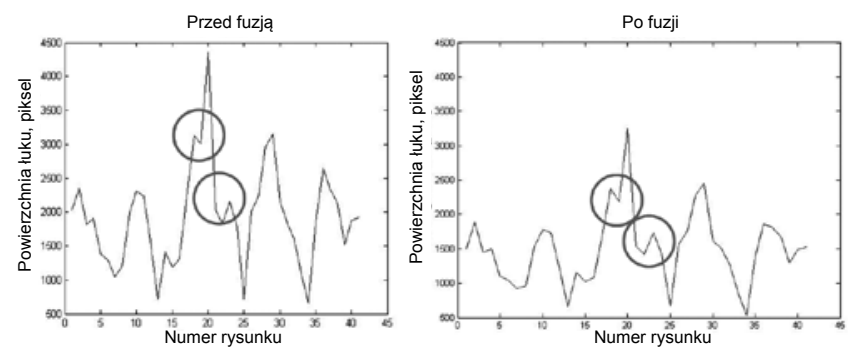

Rys. 12. Wynik analizy obrazów łuku przed fuzją i po fuzji

Fig. 12. Results of image of arc before and after fusion analysis

obrazach po fuzji. Analiza obrazów łącznych może być zatem mniej czasochłonna niż analiza obrazów wejściowych - jeden obraz zamiast dwóch. Ponadto, informacja zawarta w badanych obszarze na obrazach po fuzji jest bardziej „skondensowana” (liczba pikseli na rys. 12). $\mathrm{Na}$ rysunku 11 przedstawiono wybrane zdjęcia z sekwencji 42 zdjęć obserwacji procesu spawania liniowego. Zdjęcia zostały poddane operacjom wstępnego przetwarzania (wycięcie badanego obszaru i binaryzacja), a następnie wyznaczano wartości cech topologicznych.

Na rysunku 12 przedstawiono wykres zmienności cechy (pola powierzchni łuku), będącej odzwierciedleniem niestabilności procesu (zmiana kształtu i wielkości łuku spawalniczego). Zmiany te dla obrazów po fuzji są wyraźniejsze niż te same zmiany dla obrazów przed fuzją (zaznaczono je kółkami).

\section{Wnioski}

Wyniki wstępnych badań dotyczących oceny przydatności metod fuzji obrazów wizyjnych i termowizyjnych na potrzeby generowania łącznych obrazów łuku spawalniczego oraz monitorowania na ich podstawie procesu spawania, są obiecujące, co wskazuje na konieczność ich kontynuacji. Stwierdzono, że zaproponowane i przetestowane metody dopasowania i agregacji obrazów pozwalają na zwiększenie możliwości ich późniejszej analizy. W szczególności możliwe jest wyodrębnienie większej liczby parametrów z obrazu oraz dokładniejsza ich ocena. Zaproponowana ocena obrazów, po zastosowaniu fuzji, potwierdza również potrzebę kontynuowania badań. Należy jednak podkreślić, że zastosowanie opisanych $w$ artykule metod jest uzależnione od wielu dodatkowych czynników, które wymagają dokładnego określenia i przebadania.

Podczas badań zaobserwowano, że decydujący wpływ na jakość obrazów łącznych mają różnice w rozdzielczościach i typach detektorów oraz rodzajach obiektywów stosowanych kamer. Im większe dysproporcje w rozdzielczości kamer, tym wyniki fuzji obrazów obarczone były większą niejednoznacznością, co wynika bezpośrednio z błędów w dopasowaniu ob- razów. Różnice w rozdzielczości kamer mogą być zniwelowane przez wstępne przetwarzanie, polegające na dopasowaniu rozmiarów obiektów w wyniku skalowania lub interpolacji pikseli. Rezultaty badań wskazują, że najlepsze wyniki jakościowe i ilościowe otrzymano dla obrazów, dla których zastosowano interpolację pikseli.

Dodatkowo o jakości efektu końcowego fuzji decyduje także pole widzenia kamery, które jest wynikową ogniskowej obiektywu i rozmiaru matrycy kamery. Wyniki badań wskazują na konieczność takiego dobierania pola widzenia, aby jego obszar był wypełniony głównie przez obiekt obserwowany. Pozwala to na uniknięcie obszarów w tym samym kolorze (tzw. dużych pikseli) oraz konieczności stosowania operacji wstępnego przetwarzania obrazów. Prawdopodobnie problemy te można wyeliminować przez zastosowanie teleobiektywów. Ostatnim ważnym czynnikiem jest rodzaj wybranej do badań kamery wizyjnej, gdzie należy unikać stosowania kamer kolorowych, dla których pojawia się raster filtrów. Obraz rastra w znaczący sposób wpływa na jakość obrazów po fuzji, co bezpośrednio przekłada się na ich ilościową ocenę, dlatego jako bardziej odpowiednie do tego typu zastosowań są kamery monochromatyczne. 


\section{Literatura}

[1] Kim J.S., Son Y.T., Cho H.S., Koh K.II.: A robust method for vision-based seam tracking in robotic arc welding, Proceedings of the IEEE International Symposium on Intelligent Control 1995.

[2] Xu D., Wang L., Tan M.: Image processing and visual control method for arc welding robot, Proceedings of the IEEE International Conference on Robotics and Biomechanics, Shenyang.

[3] Smith M.I., Heather J.P.: Review of image fusion technology in 2005, in: Proceedings on Defense and Security Symposium, Orlando, FL, March 28-April 1, 2005.

[4] Smith J.S., Balfour C.: Real time top-face vision based control of weld pool size, An International Journal Industrial Robot, No. 32/2/2005.

[5] Balfour C., Smith J.S., Amin-Nejad S.: Feature correlation for weld image-processing applications, International Journal of Production Research 5(42) 2004, 975-995.

[6] Yamamoto M., Kaneko Y., Fujii K., and others.: Adaptive Control of Pulsed MiG Welding Using Image Processing System, IEEE, 1988.

[7] Węglowski M.S.: Promieniowanie widzialne użytecznym sygnałem w monitorowaniu procesu spawania, Pomiary i Automatyka 10/2006.

[8] Węglowski M.S., Mikino Z., Welcel M., Kępińska M.: Kontrola procesu spawania TIG w oparciu o promieniowanie łuku spawalniczego, Przegląd Spawalnictwa 12/2007.

[9] Nowacki J., Wypych A.: Ocena cyklu cieplnego napawania stali $13 \mathrm{CrMo}-5$ nadstopem inconel 625 metodą termowizyjną, Przegląd Spawalnictwa 12/2007.

[10] Czajewski W.: Automatyczne rozpoznawanie i śledzenie spawów przez robota przemysłowego z wykorzystaniem analizy obrazów, PAK 7-8/2002, s. 13-16.

[11] Bzymek A., Fidali M., Jamrozik W., Timofiejczuk A.: Diagnostic vision system for welded joint and welding process assesment, Problemy Eksploatacji nr 4/2008, 39-51.

[12] Goshtasby A., Stavri Nikolov: Image fusion: Advances in the state of the art, Information Fusion, Vol. 8, Issue 2, Special Issue on Image Fusion: Advances in the State of the Art, 4/2007, s. 114-118.

[13] Zitova B.: Image registration methods: a survey, Image and Vision Computing, 1123/2003, s. 977-1000.

[14] Du D., Hou R., Shao J., Wang L., Chang B.: Real-time Xray Image Processing Based on Information Fusion for Weld
Defects Detection, 17th World Conference on Nondestructive Testing, Shanghai, China, 2008.

[15] Pluim, J.P.W.; Maintz J.B.A.; Viergever M.A.; Mutual-information-based registration of medical images: a survey, Medical Imaging, IEEE Transactions on, (8) 22, 2003, 986-1004.

[16] Firooz Sadjadi: Comparative Image Fusion Analysis, IEEE CVPR'05, 2005.

[17] Li S.T., Wang Y.N.: Multisensor image fusion using discrete multiwavelet transform, Proceedings of the 3rd International Conference on Visual Computing, Mexico City, Mexico, 2000.

[18] Piella G.: A general framework for multiresolution image fusion: from pixels to regions, Information Fusion 4/2003, s. $259-280$.

[19] Blum R.S., Liu Z. (Eds.): Multi-Sensor Image Fusion and Its Applications (special series on Signal Processing and Communications), Taylor and Francis, CRC Press, 2006

[20] Waxman A.M., Fay D.A., Gove A.N., Siebert M., Racamoto J.P., Carrick J.E., Savoye E.D.: Color night vision: fusion of intensified visible and thermal IR imagery, in: Proceedings of SPIE Conference on Synthetic Vision for Vehicle Guidance and Control, 2463, 1995, s. 58-68.

[21] Burt P.J., Adelson E.H.: The Laplacian pyramid as a compact image code, IEEE Trans. Commun., 4 (31) 1983, 532-540.

[22] Toet A., van Ruyven L., Velaton J.: Merging thermal and visual images by a contrast pyramid, 7 (28) 1989, 789-792.

[23] Lejeune C.: Wavelet transforms for infrared applications, Infrared Technology XXI, SPIE, 2552, 1995, 313-324.

[24] Rockinger O.: Image sequence fusion using a shift invariant wavelet transform, in: Proc. IEEE Intl. Conference on Image Processing, 1997, III-288-291.

[25] Maruthi R., Suresh R.M.: Metrics for Measuring the Quality of Fused Images International Conference on Computational Intelligence and Multimedia Applications 2007.

[26] Xydeas C., Petrovic V.: Objective image fusion performance measure, Electronics Letters 36, 2000, s. 308-309.

[27] Bzymek A., Timofiejczuk A.: Estimation of welding process stability based on image analysis and recognition, Diagnostyka $\mathrm{nr}$ 4/2009, s. 41-44.

[28] Bzymek A., Timofiejczuk A.: Welded joint assesment on the basis of characteristic edge detection algorithm, VIII International Seminar of Technical Systems Degradation, Liptovsky Mikulas, 4/2009 (przyjęte do druku w czasopiśmie Diagnostyka).

\begin{tabular}{|c|c|c|c|}
\hline Tytuł konferencji & Data & Miejsce & Organizator \\
\hline $\begin{array}{l}\text { X Szczecińskie Seminarium } \\
\text { Spawalnicze }\end{array}$ & 2 czerwca & Szczecin & $\begin{array}{l}\text { Zakład Spawalnictwa Zachodniopomorskiego Uniwersytetu Technicznego } \\
\text { i Linde Gaz Polska Sp. z o.o. Jednodniowe wykłady, pokazy sprzętu } \\
\text { spawalniczego, spotkanie towarzyskie, zaświadczenie o szkoleniu } \\
\text { tel.: } 914624 \text { 451; e-mail: katarzyna.rudzka@pl.linde-gas.com }\end{array}$ \\
\hline $\begin{array}{l}\text { XV Gdańskie Spotkanie } \\
\text { Spawalników i XIII Pomorskie } \\
\text { Sympozjum Spawalnictwa }\end{array}$ & 8 września & Gdańsk & $\begin{array}{l}\text { Zakład Inżynierii Spajania Politechniki Gdańskiej i Linde Gaz Polska Sp. z o.o. } \\
\text { Jednodniowe wykłady, pokazy sprzętu spawalniczego, spotkanie towarzyskie, } \\
\text { zaświadczenie o szkoleniu } \\
\text { tel.: } 5851128 \text { 00; e-mail: iwona.janson@pl.linde-gas.com }\end{array}$ \\
\hline $\begin{array}{l}\text { 1. Międzynarodowa } \\
\text { Konferencja Naukowo- } \\
\text {-Techniczna Napawanie } \\
\text { - postęp i zastosowania }\end{array}$ & $\begin{array}{c}19-21 \\
\text { września }\end{array}$ & Wrocław & $\begin{array}{l}\text { Dolnośląska Sekcja Spawalnicza SIMP; Zakład Spawalnictwa Instytutu } \\
\text { Technologii Maszyn i Automatyzacji; Wydział Mechaniczny Politechniki } \\
\text { Wrocławskiej; EUROMAT, Wrocław } \\
\text { tel.: } \mathbf{7 1} 72020 \text { 74; e-mail: anna.wozna@pwr.wroc.pl }\end{array}$ \\
\hline $\begin{array}{l}\text { 53. Naukowo-Techniczna } \\
\text { Konferencja Spawalnicza } \\
\text { Nowe kierunki w procesach } \\
\text { spajania i cięcia metali }\end{array}$ & $\begin{array}{c}12-14 \\
\text { października }\end{array}$ & Poznań & $\begin{array}{l}\text { SIMP - Sekcja Spawalnicza w Poznaniu, Technika Spawalnicza Poznań, } \\
\text { Rywal RHC } \\
\text { tel.: } 602118 \text { 401; e-mail: miroslaw.nowak@techspaw.com.pl }\end{array}$ \\
\hline
\end{tabular}

